\title{
THE TRANSLATION OF ENGLISH DEVERBAL NOUNS IN KING JAMES BIBLE INTO MANGGARAI LANGUAGE
}

\author{
Fransiskus Sanur \\ Universitas Udayana \\ sanuarf@yahoo.com \\ Ketut Artawa \\ Universitas Udayana \\ artawa56@yahoo.com \\ I Nengah Sudipa \\ Universitas Udayana \\ nengahsudipa@yahoo.com
}

\begin{abstract}
This study aims to explain the types of shifts in the translation of English deverbal nouns (EDN) into Manggarai language especially the Central Manggarai Dialect (CMD) and to analyze how the types of EDN are translated into CMD. This study used a qualitative approach. The data were taken from the King James Bible (KJB) and Surak Nggeluk Reké Weru, English and CMD. The data were collected through observation method. This method was implemented at once with a note-taking technique. The result showed that a number of shifts and seven types of deverbal nouns found in the translation of EDN into CMD. The findings: (1) Level shifts: builders into lata pandé mbaru, (2) Structure shifts: workman into ata pala, (3) Class shifts: commandment into jera, (3) Unit shifts: healing into ina beti, and (4) Intra-system shifts: teachers into guru. In addition, the types of deverbal nouns: (1) Action deverbal noun: moving into gégon, (2) Agentive deverbal noun: beggar into ata lénggé, (3) Instrumental deverbal noun: charger into kepar, (4) Manner deverbal noun: blasphemy into rendak, (5) Locative deverbal noun: wallowing into purang, (6) Objective deverbal noun: creature into ata poli dédék, and (7) Reason deverbal noun: temperance into le kuasa weki.
\end{abstract}

Keywords: translation, translation shifts, deverbal nouns

\section{INTRODUCTION}

Translation is transferring the message from one language into another language. Theoretically, translation is not an easy task. It is very difficult to be done because translators must face either linguistic or non linguistic problems. There are two factors in translation; first, linguistic factors that cover words, phrases, clauses and sentences and second, non linguistic factors covering the cultural knowledge on both sources language (SL) and the target language (TL) cultures (Nababan, 1999: 20)

Each language has its own characteristics or even distinction. Therefore, 
translation from the SL into TL cannot be exact equivalents as both languages are widely different in structure and cultural background. The distinction of structural and cultural background of English and Manggarai language tend to have different way in forming the deverbal nouns.

The process of deverbal nouns in English is that by adding a derivational affix or using with or without morphological transformation. On the other hand, in Manggarai language especially Central Manggarai Dialect (CMD) has specific characteristics in forming the deverbal nouns. Some phenomenon appeared is clitic. Clitics are giving the contribution in the process of deverbal nouns in CMD (Semiun \& Jeladu, 2016)

In addition, the difference of structural and cultural background of SL and TL potentially bring a certain problem in translating process. The problem is that there is translation shifts or replacements done by translators in translating the EDN into CMD. The following is a sample of the translation of English deverbal nouns in King James Bible (KJB) into Surak Nggeluk Reke Weru or Bahasa Manggarai New Testament (BMNT).

Example:

SL: An instructor of the foolish (Romans 2:20)

TL: Hau ata toing isét bodok (ROMA 2:20)

In the SL, the noun instructor derives from the base form of the verb instruct and added with an affix (suffix: -or). In addition, the word instructor in the SL is translated into ata toing in the TL. The phrase ata toing in the TL divides into ata (people) and toing (teach, instruct, train, coach, etc.). From the example above, there are some possible questions arise: (1) What types of English deverbal noun in the SL?, (2) How is it translated into the TL?, and (3) Is there translation shift in the translation of deverbal noun from the SL into TL?, (4) Why the shifts occurred? The unique characteristic of English and CMD seems to be a complex phenomenon. Therefore, the analysis of the translation of English deverbal nouns (EDN) into Manggarai language is interested to be done. This study attempts to explain and examine the types of shifts in the translation of EDN in KJB into CMD and to know how the types of EDN in KJB are translated into CMD.

\section{RESEARCH METHOD}

The data of deverbal nouns were taken from the King James Bible (KJB) and its translation into Surak Nggeluk Reke Weru or Bahasa Manggarai New Testament (BMNT), English into Manggarai language, published by the Indonesian Bible Society- Lembaga Alkitab Indonesia in 2013. In addition, the books of the King James Bible consist of thirty-nine (39) books of the Old Testament and twenty-seven (27) books of the New Testament. However, this study merely focuses on the New Testament. Furthermore, the King James Bible $(K J B)$ is considered as the source language text (SLT) which is written in English and Surak Nggeluk Reke Weru or Bahasa Manggarai New Testament (BMNT) as the target language text (TLT) which is written in Manggarai language. Moreover, this data source was selected as the data source because of some reasons. First, the source language text namely: King James Bible (KJB) especially its new testament has its translation in Manggarai language; Surak Nggeluk Reke Weru or Bahasa Manggarai New Testament (BMNT). Second, the data source contains religious 
values, ethic, and morality. Last, the languages used in this data source contain a wide range of deverbal nouns that become an interesting challenge to be analyzed.

The method of collecting data in this study is observation method. Mason in Mackey and Gass noted that observation usually refers to "methods of generating data which involve the researcher immersing (him or herself) in a research setting, and systematically observing dimensions of that setting, interactions, relationships, actions, events, and so on, within it".(Mackey \& Gass, 2005: 175) The observation method was applied by observing the deverbal nouns in the source language text (SLT) and their translations in the target language text (TLT). Operationally, this method was implemented at once with the implementation of note-taking technique (Sudaryanto, 1993: 135).

In addition, there are two main theories used for solving the research problems in this study. They are the theory of Translation Shifts proposed by Catford (1974) was used for analyzing the first problem and the theory of Lexical Nominalization proposed by Comrie and Thompson (Shopen, 2007: 334-342) was used for analyzing the second problem of this study. The steps in collecting the data namely: read the SLT, identify the data of deverbal nouns in the SLT and then find out their equivalence in the TLT, take notes, classify the data based on the types of deverbal nouns, and the data to be analyzed.

\section{DISCUSSION}

The data were analyzed based on two formulated research problems namely: first the types of translation shifts in the translation of English deverbal nouns in King James Bible (KJB) into Manggarai language and second the types of English deverbal nouns in King James Bible and their translations into Manggarai language.

\section{Translation Shifts}

Shifts departures from formal correspondence in the process of going from the SL (source language) to the TL (target language) (Catford, 1974: 73). Shifts occur when the source language text is translated into different grammatical or phonological form in the target language text. In addition, Catford added that there are two major types of shifts, they are level shifts and category shifts. Category shifts have four sub-types of shifts, namely: structure shifts, unit shifts, class shifts, and intra-system shifts (Catford, 1974: 73-82).

\section{Level Shifts}

Shift of level is when a source language item at one linguistic level has a target language translation equivalent at a different level. It includes shifts from grammar to lexis and vice-versa (Catford, 1974: 73).

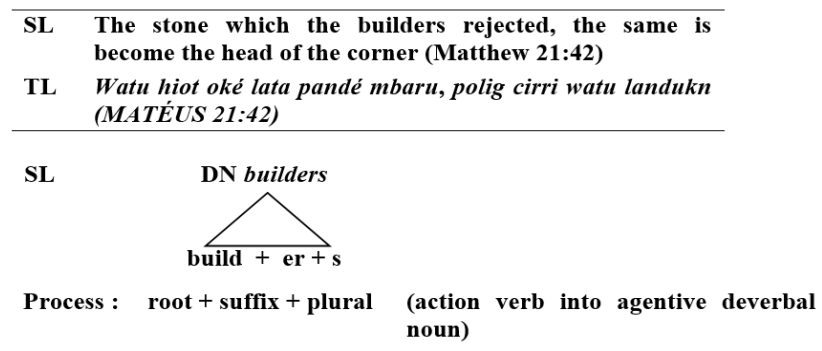


Data (1.1) refers to level shift. From the above data, the word builders in the SL is derived from the root form of verb: build, in addition, it is added with an affix (suffix: $-e r$ ) and the plural $s$, furthermore, it becomes a noun denoting an agentive deverbal noun. Moreover, the noun builders in the SL was translated into lata pandé mbaru in the TL. It shows that the SL is noun but is changed into a clause in the TL. The distinction of SL and TL is that the grammatical item of SL is changed into lexical items in the TL..

Aikhenval (in Shopen, 2007: 1) stated that grammatical words in most languages have an internal structure. A grammatical word consists of a number of grammatical elements which (i) always occur together, rather than scattered through the clause (the criterion of cohesiveness); (ii) occur in fixed order; and (iii) have a conventionalized coherence and meaning. A grammatical word must include at least one inflectional morpheme. For example: builders in the SL. The plural s which constitutes grammatical word cannot stand alone but it must be attached to another grammatical word.

On the other hand, lexical units are form-meaning association is hardly predictable on the basis of the meaning of their components, are not limited to a list of words only. Often, a combination of words, a phrase, or even a sentence can be idiomatic, or non-compositional. For example: a clause lata pandé mbaru in the TL can be seen in the following description.

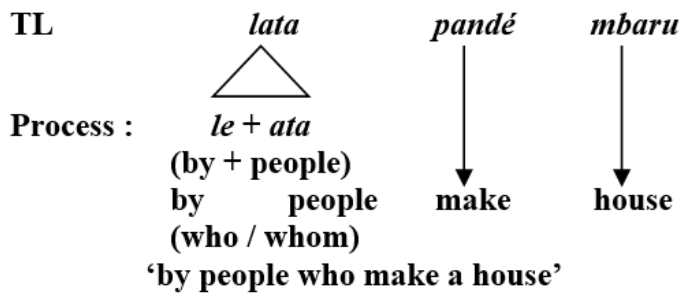

From the above data, it denotes that the grammatical item builders in the SL is translated into lata pandé mbaru in the TL. Partially, the word lata derives from the preposition le and combine with ata, then $e$ is dropped, it becomes lata (by people), the word pandé (make), and mbaru (house). The clause lata pandé mbaru is literarly translated in English by people make house. For a structure and meaning purposes, a grammatical function who/whom or relative pronoun is required. Thus, the clause lata pandé mbaru is partially or literarly translated in English by people who make a house or by whom making a house. The data show that unlike the SL, in the TL there is no special marker to nominalize agentive deverbal noun.

\section{Category Shifts}

Category shifts refer to unbounded and rank-bounded translation (Catford, 1974). The first being approximately normal or free translation in which source language and target language equivalents are up at whatever rank is appropriate. It is clear that category shift is unbounded, which might be normal of free translation, depends on what rank is appropriate. It includes structure shifts, class shifts, unit shifts, and intra-system shifts.

a) Structure shifts

Structures shift where one element is typically obligatory while other ele- 
ments are optional, an agreement between the head and its modifiers, are usually observed in some languages (Catford, 1974: 77). In the English nominal group, for instance, this agreement is observed between articles and nouns but overlooked between nouns and adjectives.

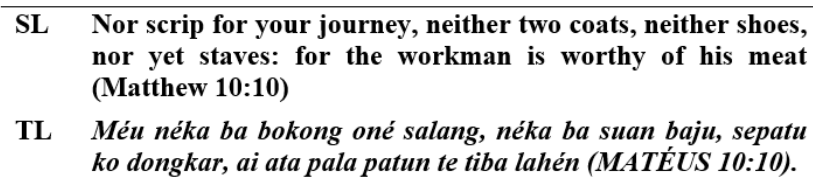

TL Méu néka ba bokong oné salang, néka ba suan baju, sepatu ko dongkar, ai ata pala patun te tiba lahén (MATÉUS 10:10).

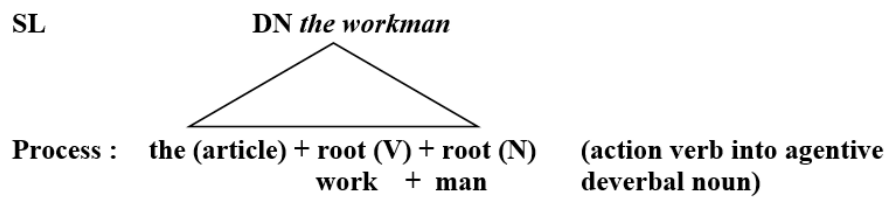

Data (1.2.1) refers to structure shift. From the above data, the noun phrase the workman consists of an article the and a noun workman. The the bound word workman is derived from the root form of the verb work and the root form of the noun man. In addition, the noun workman means one who works. Furthermore, the noun phrase the workman was translated into ata pala in the TL. The data show that an article the was not translated in the TL. It is clearly seen that in the $\mathrm{SL}$, an article the modifies the head noun workman. So the pattern is modifier + head N. Moreover, in the TL ata pala consists of ata (people) as a noun and pala (work) is a verb. In the TL, the word ata plays as head and pala as modifier. The structure shift occurs between the SL and the TL can be seen as the following picture.

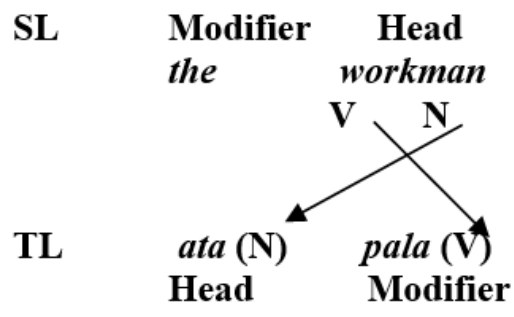

From the above data, it is obviously seen that there is a structure shift occurred between the SL and the TL. The shift is occurred between noun in the SL and its translation into noun phrase in the TL. The data show that internally, the noun workman in the SL is shifted into noun phrase ata pala in the TL in which the initial-position of SL is verb while in the TL is noun and the final-position of $\mathrm{SL}$ is noun while in the TL is verb.

\section{b) Class shifts}

Class shifts following Halliday's definition "that grouping of members of a given unit which is defined by operation in the structure of the unit next above (Catford, 1974: 78). Structure shifts entail class shifts. This is because of the "logical dependence of class on structure". Class shift occurs when the translation 
Vol. 3, No. 1, Januari 2019, 15

Available Online at https://ejournal.warmadewa.ac.id/index.php/kulturistik

DOI: dx.doi.org/10.22225/kulturistik.3.1.935

equivalence of a source language item is a member of a different class from the original item. It is a change in word class.
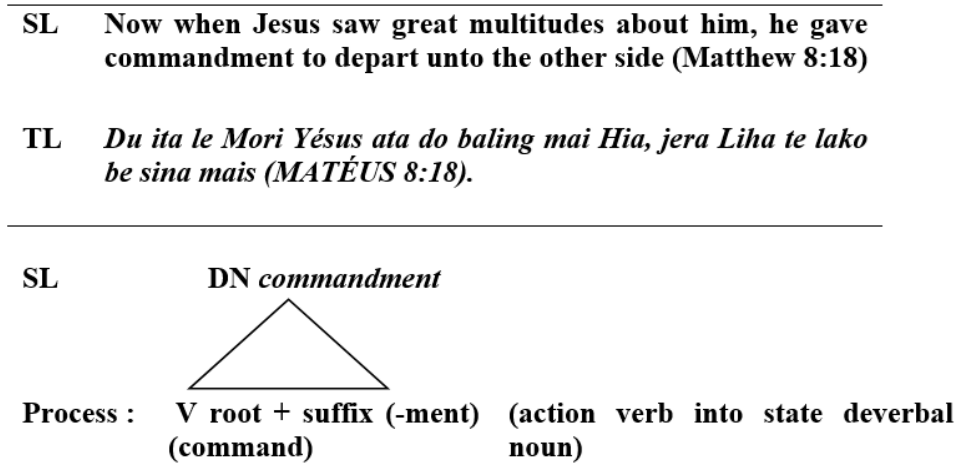

Data (1.2.2) refers to class shift. From the above data, the word commandment is derived from the root form of verb: command, in addition, the verb command is followed by an affix (suffix: -ment), thus, it becomes a noun. The verb command is order (of somebody in a position of authority) to tell somebody to do something (Hornby, 2005: 300). From the above data, it shows that the noun commandment in the SL was translated into jera in the TL. In the TL jera refers to a verb means to order, to command, etc. It denotes that there is class shift in which the word commandment as a noun in the SL is changed into a verb jera in the TL. In this case, the class shift is a change in word class. It is a change from a noun into a verb. It is clearly seen as the following description.

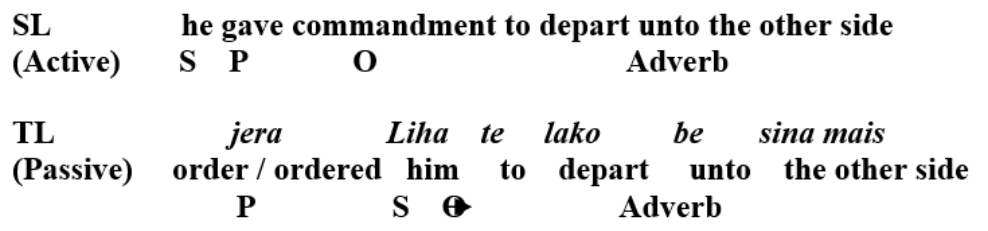

From the above data, it is obviously seen that the construction of the sentence in the SL is active form while in the TL is passive form. The data show that the main reason why there is class shift because translator translated the active sentence of the SL into passive form in the TL.

\section{c) Unit shifts}

The descriptive units of the grammar of any language are arranged into meaningful stretches or patterns. One single instance of these patterns is called unit. Catford (1965:79) states that unit shifts mean changes of rank that is, departure from formal correspondence in which the translation equivalent of a unit at one rank in the SL is a unit at a different rank in the TL. It includes shifts from morpheme to a word, word to phrase, clause to sentence, and vice versa. 
Vol. 3, No. 1, Januari 2019, 16

Available Online at https://ejournal.warmadewa.ac.id/index.php/kulturistik

DOI: dx.doi.org/10.22225/kulturistik.3.1.935

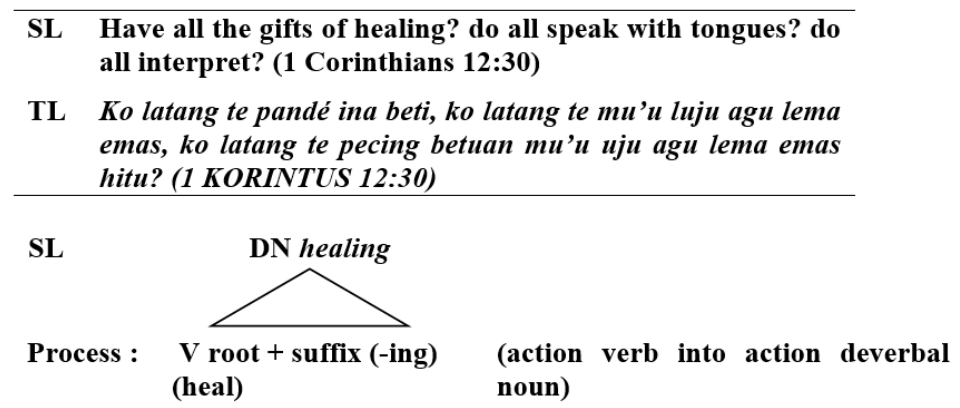

Data (1.2.3) deals with unit shift. From the above data, the word healing in the SL is derived from the base form of the verb heal, in addition, it is added with an affix (suffix: -ing), thus, it becomes a noun. Categories healing as noun, he also defines healing is the process of becoming or making somebody or something healthy again, or the process of getting better after an emotional shock (Hornby, 2005: 719). Furthermore, the noun healing in the SL was translated into ina beti in the TL. In this case, the form of word in the SL is translated into the form of phrase in the TL. The tree diagram bellow shows how the unit of word in SL is changed into unit of phrase in TL.

\section{SL: Word unit healing}<smiles></smiles>

\section{TL: Phrase unit ina beti}

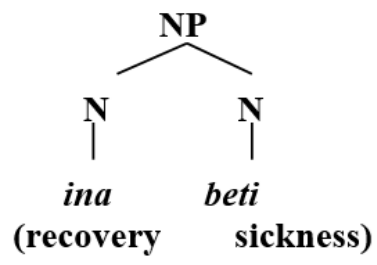

d) Intra-system shifts

Intra system shifts refer to those changes that occur internally within a system. Catford (1965:80) states intra-system shifts happen when a term is singular in the source text and its textual equivalent is plural, or vice versa (a change in number even though the languages have the same number system).
SL Desiring to be teachers of the law; understanding neither what they say, nor whereof they affirm (2 Timothy 1:7)
TL Isé ngoéng te ciri guru Adak Taurat, kalim po weki rud isé toé pecing apa ata poli curup de rud agu pu'ud sangéd curupd situ (2 TIMOTÉUS 1:7)

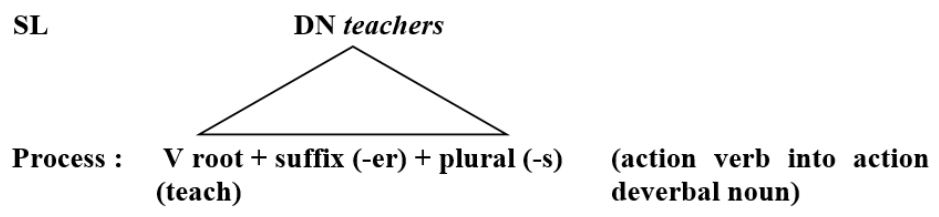


Data (1.2.4) belongs to intra-system shift. From the above data, the word teachers in the SL comes from the base form of the verb teach, and it is added with an affix (suffix: $-e r$ ) and the plural $-s$. In addition, it becomes a noun. The plural $-s$ in SL reveals the noun teacher is more than one person.

Furthermore, the word teachers in the SL was translated into guru in the TL. From the above data, it shows that the plural in the SL was changed into singular in the TL. Unlike in the SL, it denotes a special marker to reveal plural, in this case, it is marked by $s$ at the end of a verb, while in the TL, it attempts to share the implicitness meaning whether guru means plural or singular.

\section{Types of Deverbal Nouns}

Seven types of deverbal nouns. They are action or state deverbal noun, agentive deverbal noun, instrumental deverbal noun, manner deverbal noun, locative deverbal noun, objective deverbal noun, and reason deverbal noun (Comrie \& Thompson, 2007: 334-342).

\section{Action or State Deverbal Nouns}

This type of nominalization is to form noun by attaching derivational suffixes to denote action. The purpose of this nominalization is to create action noun from action verb and to form state noun from state verb (Comrie \& Thompson, 2007: 335).

SL If these lay a great multitude of impotent folk, of blind, halt, withered, waiting for the moving of the water (John 5:3)

TL Do kétas ata beti halas kid oné molang situ: Mangas ata buta, ata denggo-doat wa'i agu ata péko. Isé géréng gégon waé tiwu hitu (YOHANÉS 5:3)

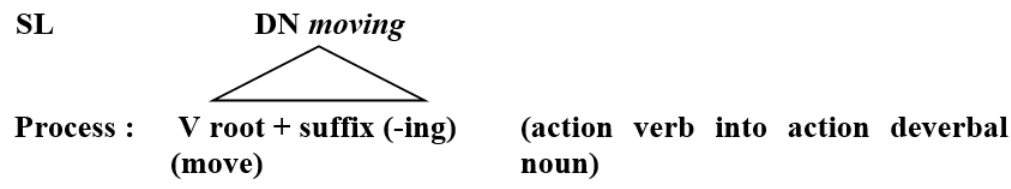

Data (2.1) belongs to action deverbal noun. The word moving in the SL is called as action deverbal noun because it is derived from the base form of verb move and it is added with an affix (suffix: -ing). In addition, it becomes a noun. The data shows that an action noun is derived from an action verb. The purpose of action nominalization is to create action noun from action verb (Comrie \& Thompson, 2007: 335). Furthermore, the noun moving denotes for the acts of something going to move or going to change its residence or location to another. Thus, the moving of the water in this case means the act of the water going to move or change its residence or location to another place.

Moreover, the noun moving in the SL was translated into gégon in TL. The word gégon derives from the base form of verb gégo and it is added with the enclitic $n$. It is obviously shown in the following picture. 


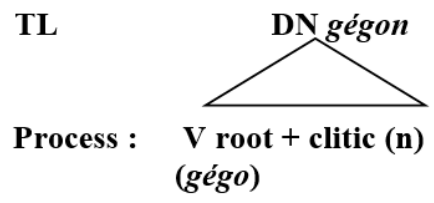

The data show that the deverbal noun gégon is derived from the base form of verb gégo (move, shake) and added with clitic $n$. The occurrence of the enclitic $n$ changes the verb gégo into noun. Similar to SL, in the TL the noun gégon also belongs to action deverbal noun in which the action verb gégo creates the action noun gégon. The enclitic $n$ denotes for possessive pronoun; the third singular person /his, her, its/ (Semiun \& Jeladu, 2016) Thus, the word gégon implicitly means gégo Diha (its move) (the possessive pronoun Diha (its) in this case refers to waé tiwu hitu (the water').

The data show that in the SL, morphologically, the process of an action deverbal noun is formed by the inflectional suffix while in the TL, it is formed by adding clitic in verb root. It denotes that linguistically, there is distinction in structure of both SL and TL.

\section{Agentive Deverbal Noun}

The process of agentive deverbal noun is changing verbs into nouns by attaching derivational suffix to form nouns denoting actor or agent (Comrie \& Thompson, 2007: 336)

\footnotetext{
SL And it came to pass, that the beggar died, and was carried by the angels into Abraham's bosom (Luke 16:22)

TL Ného cepisan, matay ata lénggé hitu, mai malékat dadé hia lobo pa'a di Abraham (LUKAS 16:22)

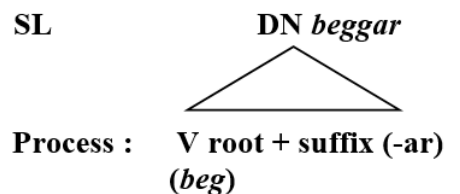

(action verb into agentive deverbal noun)
}

Data (2.2) refers to agentive deverbal noun. The word beggar in the SL is derived from the base form of the verb beg, and it is added with an affix (suffix: $a r$, in addition, in English suffix - ar means relating to, being a person who. In this case, the word beggar means a person who lives by asking people for money or food (Hornby, 2005: 126). It shows that, this type of verbal nominalization is categorized as agentive deverbal noun.

Furthermore, the word beggar in the SL was translated into ata lénggé in the TL. The phrase ata lénggé in the TL divides into two lexical items: ata (people) and lénggé (poor, begging, backward, etc). Partially the word beg in the SL belongs to verb and was translated into an adjective lénggé in the TL. The phrase ata lénggé means people who are poor. The data show that the free word ata (people) in the TL uses to denote actor or agent of the activity.

Moreover, the data show that (1) the word unit beggar in the SL was translated into the phrase unit ata lénggé in the TL. It denotes that in the SL entails the 
level of morphology while in the TL bears the level of syntax, (2) the morphological process of a deverbal noun in the SL is by derivational suffix while in the TL is by using a free word ata. The constraint is that in terms of structure there distinction of both SL and TL; in the SL, it has special marker to nominalize verb while in the TL, it does not.

\section{Instrumental Deverbal Noun}

Some languages there is a (typically morphological) process for forming from an action verb into a noun meaning "an instrument"(Comrie \& Thompson, 2007 : 338). In English, of course, is similar: -er is used in both functions: they are as agentive and as instrumental. This type of nominalization is that nouns are formed from action verbs but are meant instrument.

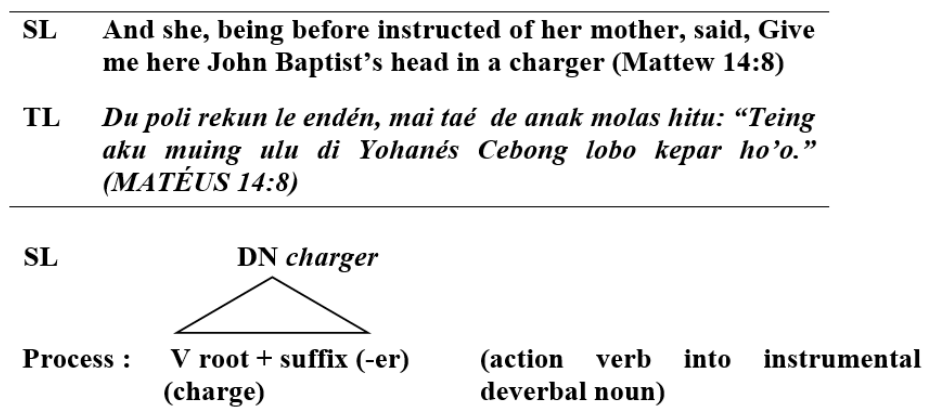

Data (2.3) is the type of an instrumental deverbal noun. The noun in the SL is formed from an action verb but it reveals an instrument. In this case the noun charger is derived from the base form of the verb charge, and it is added with an affix (suffix: -er). In addition, it becomes a deverbal noun. The noun charger means a bowl, or a platter or flat wooden trencher, or deep dish, or a shallow vessel for receiving water or blood, also for presenting offerings of fine flour with oil (www.biblestudytools.com).

Furthermore, the noun charger in the SL was translated into kepar in the TL. In this case, the word kepar (tray) is a noun. It refers to a flat piece of wood, metal or plastic with raised edges, used for carrying or holding things especially food and drink. Moreover, in terms of shape, material, and function there is no difference between charger in the SL and kepar in the TL. Thus, kepar in the SL denotes an instrumental.

The distinction of both SL and TL is that in the SL is a deverbal noun while in the TL is purely a noun.

\section{Manner Deverbal Noun}

Special derivational affixes are attached to roots of verbs to form nouns to denote manner or way of doing something (Comrie \& Thompson, $2007: 339$ ). English gerunds are like this: his walking can refer either to the fact or occurrence of his walking or to the way he walks. 
Vol. 3, No. 1, Januari 2019, 20

Available Online at https://ejournal.warmadewa.ac.id/index.php/kulturistik

DOI: dx.doi.org/10.22225/kulturistik.3.1.935

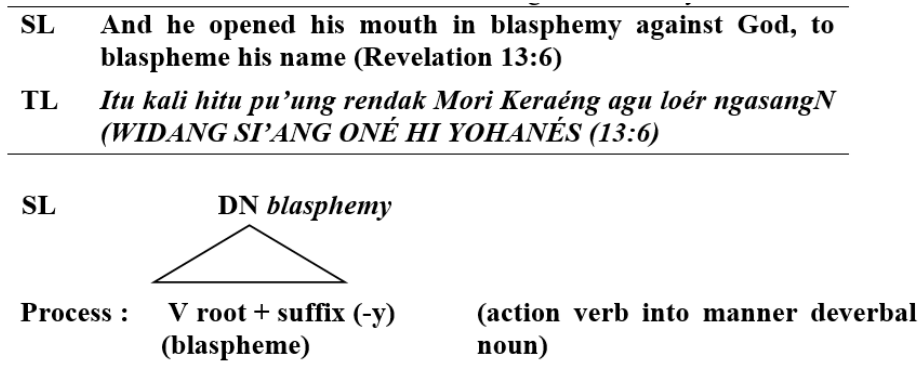

Data (2.4) is considered as manner deverbal noun. The word blasphemy in the SL derives from the base form of the verb blaspheme, and it is followed by an affix (suffix: $-y$ ), in addition, it becomes a noun. Blasphemy is behavior or languages that insults and shows a lack respect for God or religion. In this case, blasphemy is the way of how he or she behaves God or other religion (Hornby, 2005: 148). Thus, the word blasphemy reveals a manner deverbal noun.

Furthermore, the word blasphemy in the SL was translated into rendak in the TL. The word rendak in the TL is a noun, it reveals the expression or languages that insults and shows a lack respect for God, or for somebody, or something. Moreover, to degrade, to blaspheme, to humiliate, to swear etc. about God, or somebody, or something in the TL is using loér.

\section{Locative Deverbal Noun}

Locative deverbal nouns are nouns that resulted from the nominalization processes to denote location where an action is done (Comrie \& Thompson, $2007: 340$ ).

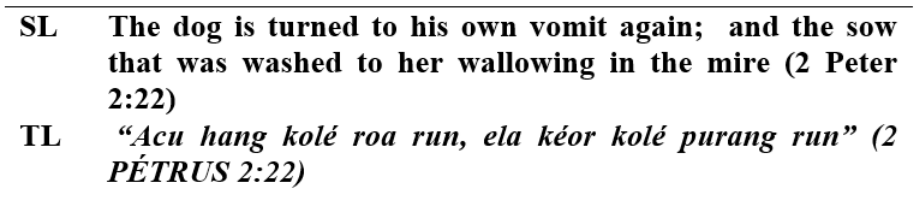

SL

$$
\text { DN wallowing }
$$

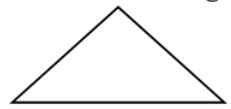

Process : $\quad V$ root + suffix (-ing) (wallow)

(action verb into locative deverbal noun)

Data (2.5) denotes a type of locative deverbal noun. From the above data, the word wallowing in the TL is derived from the base form of the verb wallow (to lie or roll about in water or mud), and it is added with an affix (suffix: -ing), in addition, it becomes a noun. In this case, the word wallowing is synonymous with words mud-hole or trash dump, or the place where animals wallow or swim.

Furthermore, the word wallowing in the SL was translated into purang in the TL. In the TL, the word purang refers to a pond, or a mud-hole, or a mud puddle, etc. where some animals such as: pigs, wild boars, buffalos, etc. wallow, bathing, or swim.

The data show that the deverbal noun of the SL was translated into a pure 
noun in the TL.

\section{Objective Deverbal Noun}

This is a type of nominalization to show result of an activity. Many Bantu languages such as Zulu, Si-Luyana, Sundanese and Indonesian, as reported by Robins (in Comrie \& Thompson, 2007: 340-341), perform this process of nominalization.

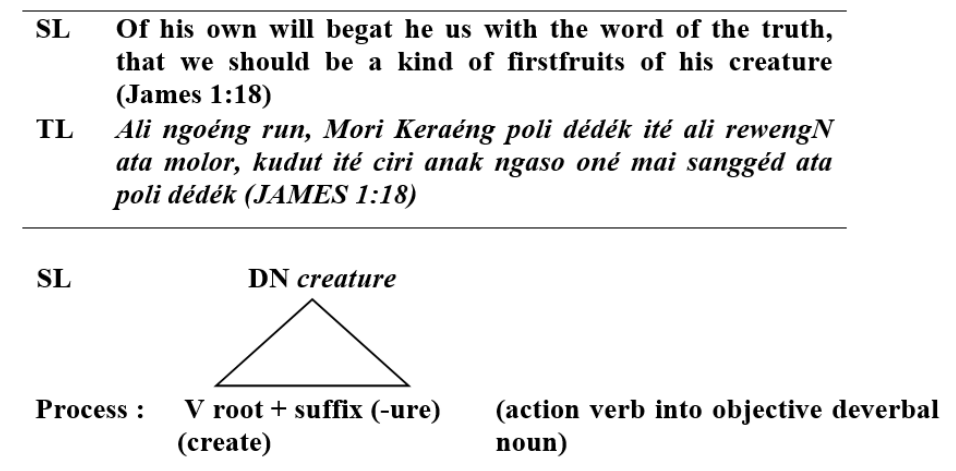

Data (2.6) is a type of objective deverbal noun. The word creature comes from the base form of verb create, and because of a morphological or an affix (suffix: -ure) process it becomes a noun creature. Suffix -ure is to reveal the action, or process or result of an activity (Hornby, 2005: 75).

In addition, the word creature in the SL was translated into ata poli dédék in the TL. The phrase ata poli dédék has each partial meaning. They are ata (people), poli (has/have/had), and dédék (made). So, ata poli dédék literally translated into people has made, or who or that has made. It refers to something or living thing that has made. Furthermore, in the TL the word dédék (made) is a noun resulted from the verb pandé (make). There is no specific explanation about the process of how the verb pandé becomes noun dédék in the TL. However, from the above data, it seems to show that there is no specific marker for nominalizing verb to denote result of activity in the TL. The free phase ata poli (who/that has/ have/had) is an evidence for forming an objective nominalization in the TL.

\section{Reason Deverbal Noun}

The purpose of this nominalization is to form nouns from verbs denoting reason by attaching affixes to the verb root (Comrie \& Thompson, 2007: 339).
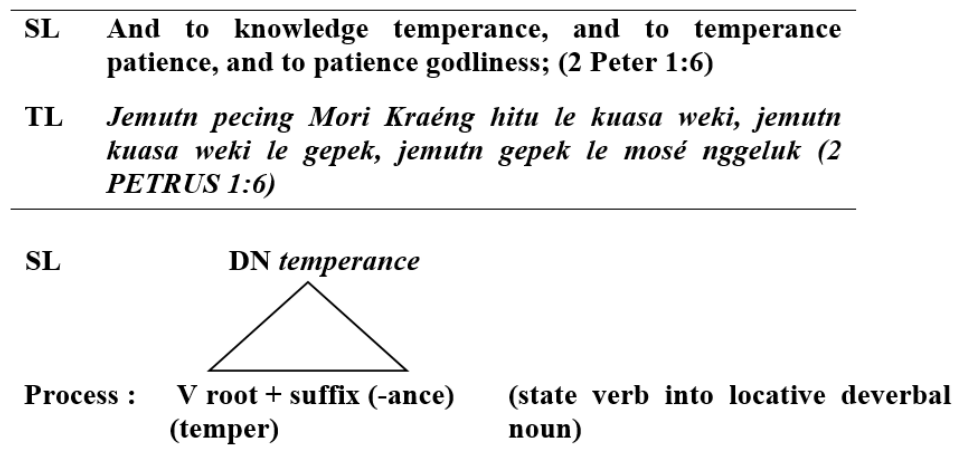
Data (2.7) belongs to reason deverbal noun. The word temperance in the SL is derived from the base form of the verb temper, and it is added with an affix (suffix:-ance). From the above data, it shows the reason deverbal noun. In this case, the word temperance explicitly reveals the reason for knowledge, the reason for temperance is patience, and the reason for patience is godliness.

In addition, the word temperance in the SL was translated into le kuasa we$k i$ in the TL. It is obviously shown in the following picture.

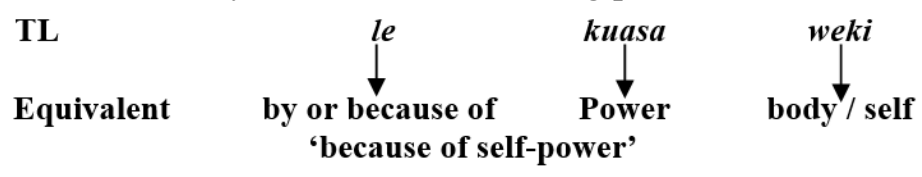

The phrase le kuasa weki in the TL can split into le (by, because of), kuasa (power), and weki (body / self). Thus, le kuasa weki means because of selfpower. The data show that the free word le (because of) is used in order to denote reason in the TL.

\section{CONCLUSION}

Firstly, it can be drawn the conclusion that there are translation shifts found in the translation of English deverbal nouns in King James Bible (KJB) into Manggarai language. The translation shifts occurred in two major types of shifts such as: level shifts and category shifts. (1) Level shifts. For example: builder in the SL was translated into lata pandé mbaru in the TL. In addition, (2) Category shifts namely: (2a) Structure shifts. For example: the bound word workman in the SL was translated into a noun phrase ata pala in the TL, (2b) Class shifts. For example: the noun commandment in the SL was translated into the verb jera in the TL, (2c) Unit shifts. For example: the word healing in the SL was translated into a noun phrase ina beti in the TL, and (2d) Intra-system shift. For example: the word teachers in the SL was translated into guru in the TL.

Secondly, it can be drawn the conclusion that there are seven types of deverbal nouns found namely: Action or state deverbal noun, agentive deverbal noun, instrumental deverbal noun, manner deverbal noun, locative deverbal noun, objective deverbal noun, and reason deverbal noun.

\section{REFERENCES}

Catford, J. C. (1974). A linguistic theory of translation. London: Longman.

Comrie, B., \& Thompson, S. . (2007). Lexical Nominalization. In Language typology and syntactic description. Cambridge: Cambridge University Press.

Hornby, A. S. (2005). Oxford advanced learner's dictionary seventh edition. Oxford: Oxford University Press.

Mackey, A., \& Gass, S. M. (2005). Second language research: methodology and design. Mahwa, N.J.: Lawrence Erlbaum Associates.

Nababan, R. (1999). Teori Menerjemah Bahasa Inggris. Yogyakarta: Pustaka Pelajar.

Semiun, A., \& Jeladu, K. (2016). Verb Nominalization of Manggarai Language: The Case of Central Manggarai Dialect in West Flores Indonesia. American Research Institute for Policy Developmen. International Journal of Language and Literature, 4. 


\section{Sulliturisistillk \\ KULTURISTIK JURNAL BAHASA \& BUDAYA}

Vol. 3, No. 1, Januari 2019, 23

Available Online at https://ejournal.warmadewa.ac.id/index.php/kulturistik

DOI: dx.doi.org/10.22225/kulturistik.2.2.717

Shopen, T. (2007). Language typology and syntactic description. Cambridge: Cambridge University Press.

Sudaryanto. (1993). Metode dan Teknik Analisis Bahasa. Yogyakarta: Duta Wacana University Press. 